\title{
Religious Beliefs And Wealth Accumulation
}

E. Anne York, Meredith College, USA

Marilyn Dutton, Meredith College, USA

\begin{abstract}
One of the more interesting findings in the research on household wealth is the relationship between religion and wealth accumulation. In contrast to previous studies that use denominational affiliation, we use a more precise measure of religious belief constructed from responses to survey questions regarding interpretation of the Bible. Regression results indicate that households with more literalist Biblical beliefs have lower net worth overall. Additional analysis using quantile regression reveals that this relationship holds only for the upper half of the wealth distribution. There is no relationship at lower levels of wealth. Finally, while more literalist households are less likely to have an investment account or to have ever received an inheritance, they are more likely to own a home and to have a positive net worth.
\end{abstract}

Keywords: Wealth Accumulation; Religion; Quantile Regression; National Survey of Families and Households

\section{INTRODUCTION}

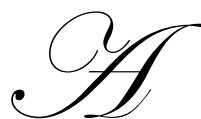

s a measure of economic well-being, household wealth is at least as important as income. Wealth enhances current consumption, ensures future consumption for the current generation, and through bequests augments the consumption of future generations. The disparity in wealth is well recognized, but the growing gap between the wealthiest and the poorest segments in the U.S. is nevertheless disturbing. Between 1983 and 2007 the growth rate in net worth was much greater for the top wealth groups than for groups lower in the wealth distribution. In fact, the average wealth of the poorest $40 \%$ actually declined by $63 \%$ during that period (Wolff 2010). This growing disparity in wealth can have adverse social and economic consequences especially if it is accompanied by declining economic mobility. In order for policy makers to implement measures that address this issue, it is important to understand the factors that influence wealth accumulation. Some of the causes of wealth differences may be easily remedied, but others may not be so amenable to change. Knowing the difference can assist in devising efficient and effective strategies to improve the well-being of those households at the lower end of the wealth distribution.

The factors that affect household wealth have been the subject of a number of papers. Stiglitz (1969) was one of the first papers in the economics literature to address the question of the determinants of household wealth accumulation and the variations in wealth holdings across households. That paper laid a theoretical groundwork by constructing a model in which the variation in wealth among individuals is explained by the form of the consumption function, the heterogeneity of labor skills, inheritance policies and variations in the birth rate.

Previous research has also found an association between religious participation and a variety of economic outcomes. These include earnings (Steen 1996; Lipford and Tollison 2003), educational attainment (Darnell and Sherkat 1997; Sherkat and Darnell 1999; Lehrer 1999), labor supply (Lehrer 1995; Heineck 2004), investment in human capital (Chiswick 1986; Glass and Jacobs 2005), and the remitting behavior of immigrants (Kelly and Solomon, 2009).

One of the more interesting findings is the relationship between wealth and religious affiliation. Keister $(2003,2007,2008)$ shows that Jews have more wealth accumulation than members of other religions; that Catholics have had greater upward wealth mobility; and that Conservative Protestants have less wealth than members of other denominations. In her work, Keister distinguishes between the direct and indirect effects of religion on wealth. She contends that religion affects wealth directly by inculcating values that influence work and financial decisions and by establishing social contacts through which individuals learn about saving and investing, all of which can 
influence wealth accumulation. Keister also argues that religion affects wealth indirectly by influencing individuals' choices regarding educational attainment, fertility and family size, occupation, and career advancement, all of which have been shown to be related to household wealth. Similar to other studies of religion and wealth (e.g. Lehrer 2004; McCleary and Barro 2006), Keister uses denominational affiliation as the religion variable.

In this paper, we also examine the relationship between wealth and religion but we extend the research in two ways. First, we construct a specific measure of religious belief and use that in the wealth equation. We argue that because people attend places of worship for a variety of reasons, including social interaction, using denomination as the religion variable makes it impossible to isolate the effect of religious belief and values from the effect of social contacts on wealth. By focusing on specific religious beliefs rather than denomination, we are better able to identify the direct effect of religious belief separate from the other influences of religion on a household's propensity to accumulate wealth.

A second extension is that we examine the effect of these beliefs across the wealth spectrum. We assert that a tendency to invest in assets that are lower risk, but carry a lower return, may have different implications for wealth accumulation at different points in the wealth distribution; that is, religious belief may affect the wealth of households at the lower end of the distribution differently from those at the upper end. We use quantile regression to examine this possibility and also use logistic regression to analyze the probability of having certain types of assets.

The rest of the paper is organized as follows. In the next section we establish the rationale for why religious belief might be expected to affect wealth accumulation and develop a model that specifies the relationship between wealth and religious belief. In the Data section, we describe the data set and explain the variables used in the model. We report the results of a set of empirical tests in the Results section. The last section contains concluding remarks.

\section{MODEL AND HYPOTHESES}

We focus on the direct impact of religious belief on wealth separate from other effects of denominational affiliation such as social interaction. To do this, we devise a measure of what we call "Biblical literalism" using the following criteria: (1) a literal interpretation of the Bible and (2) the application of the precepts of the Bible to everyday life. For our purposes, the more strongly a person adheres to both criteria, the higher the measure of Biblical literalism.

By categorizing respondents according to belief rather than denomination, our approach differs from previous studies. These studies relied on coding schemes similar to that developed by Smith (1990) or Steensland, et al. (2000), which placed respondents into categories based on their religious affiliation rather than their beliefs. However, as Steensland, et al. themselves state, "While affiliation and religious beliefs are certainly correlated, they are analytically and empirically distinct dimensions of religiosity" (296). The distinction between belief and affiliation is highlighted by a study by Hackett and Lindsay (2008) which showed that the population defined by denominational affiliation was very different from that defined by religious belief.

It isn't initially obvious what the direct effect of literal Biblical interpretation on wealth would be since the effects could well be contradictory. On the one hand, a strong admonition to practice thrift and lead a clean life devoted to hard work and good works would support the accumulation of wealth. Proverbs 10:4 states that "Lazy hands make for poverty, but diligent hands bring wealth." The Parable of the Talents in Matthew 25: 14-30 is widely interpreted as meaning that there are rewards for those who are good stewards of what they have received from God, including their wealth, and adverse consequences for those who are not good stewards.

On the other hand, a variety of factors could have just the opposite result. Because people who adhere to a literal interpretation of the Bible may generally be more careful and cautious, taking this approach to savings decisions would lead to investment in lower risk, lower return assets, ultimately resulting in a lower level of total wealth. Biblical literalists are also more likely to practice tithing, sacrificial giving, and give more money to charity (see Regnerus et al. 1998). In that case, they would devote a smaller fraction of their earnings to savings and 
investment, which then leads to a lower accumulation of wealth. And lastly, there are many scriptures in the Bible that warn against the "love of money" and how pursuing wealth and prosperity can detract from one's relationship with God. The passages in Luke 19: 21-26, Mark 4:19, Mark 8:36, 1 Timothy 6:9-11, and James 5:1-6 are examples of this message.

Frugality and prudence are important up to a point, but beyond that point the amount of investment and the allocation of assets should become important. A lower rate of investment combined with a preference for safer but lower return assets will eventually have an adverse effect on wealth. In that case, we would expect that Biblical literalism could very well have an overall negative impact on wealth. At the same time, the relative importance of these opposing forces would vary at different levels of wealth. Being financially careful and conservative would serve to protect the wealth of those households with little or no wealth. But higher risk is usually associated with higher returns, so risk aversion would have an increasingly negative effect at higher levels of wealth, especially if it is associated with a lower rate of investment overall.

These considerations lead us to a set of hypotheses regarding the wealth effects of religious belief. Our first hypothesis is that Biblical literalism has an overall negative impact on net worth. Our second hypothesis is that this negative impact is not the same across the wealth distribution. And finally, we predict that those with more literalist beliefs would have a less risky investment mix.

We use the following model:

Wealth ${ }_{i}=\alpha+\beta\left(\mathrm{RB}_{i}\right)+\gamma \mathrm{I}_{i}+\lambda \mathrm{D}_{i}+\varepsilon_{i}$

where the wealth of each household, as measured by net worth, is a function of religious belief, income, and a set of social and demographic variables that have previously been shown to affect wealth differences. First, we use a likelihood-based general linear regression of the model to test the hypothesis that an increasing degree of Biblical literalism has an adverse effect on wealth. Next, we use the model again in a quantile regression analysis to examine whether the effects of religious belief are the same for all levels of wealth. Finally, we examine the effect of religion on asset allocation with a set of logistic regressions on the probability of having a savings account, of having an investment account, of having debt, of owning a home, of ever receiving an inheritance, and of having a positive net worth.

\section{DATA DESCRIPTION}

We employ data from the National Survey of Families and Households (NSFH), one of the few national datasets with variables on both wealth and religion. This survey was conducted in three waves: 1987 to 1988, 1992 to 1994, and 2002 to 2004 (Sweet and Bumpus 1996) and includes data from more than one respondent in the household. We use Wave 2 (1992-1994) of the data because Wave 3 did not include the previous full sample and only Wave 2 has a "best measures" construction of income, which uses the income, asset, and debt information from the respondent that is judged to be more accurate. A randomly selected adult in each household was designated the primary respondent with the spouse or cohabitating partner designated as the secondary respondent. Both primary and secondary respondents were asked nearly identical survey questions. The survey gathered a wide array of demographic and financial information and asked respondents questions regarding their attitudes on a variety of family and social issues. Two of these questions related to religious beliefs.

The Wave 2 data contained responses from 10,007 households. We imposed minimum age restrictions similar to those used in other studies and limited our sample to households in which the primary respondent was at least 25 years old, an age at which most individuals have entered the workforce and begun to acquire assets. We also confined our data set to households in which the primary respondent was Black, White, or Hispanic. After imposing these minimum age and race restrictions and after deleting households with missing observations, we had a sample of 6,296 households, of which 3,594 had a secondary respondent.

The NSFH is designed to have an oversample of Blacks, Puerto Ricans, Mexican Americans, single-parent families, families with step-children, cohabitating couples, and recently married persons and hence includes sample 
weights to help the sample better represent the population. Johnson and Elliott (1998) examined descriptive and regression results that use the NSFH data in order to determine the impact of using or not using the sample weights. They had found that many research articles that use the NSFH data do not use the sample weights. Their finding is that measures of central tendency are more impacted by the use of weights than are measures of covariation. We therefore take account of the sample weights in our analysis of means and medians but not in the regression results.

\section{Measurement of Wealth}

We used net worth as our measure of wealth, and we had to construct this variable from the raw data. The survey asked respondents to report the value of all assets and debts that they and/or their spouse held. While the questions differentiated between labor market earnings received by each spouse in a household, no such distinction was made for assets, debts or income from interest and dividends. All of these were treated as belonging to the household. Assets included the value of the primary residence, any other real estate, any business or farm, vehicles, savings, and financial investment accounts. Debts included all mortgages on real estate, loans on vehicles, credit card debt, school loans, home equity loans, bank and installment loans, outstanding bills and any other debt. We calculated net worth as total assets minus total debts.

To conduct our tests, we needed continuous data for all financial variables, but the respondents were not required to give specific dollar values for the balances in their savings and investment accounts. Instead, they were asked to indicate the total value for each of these two accounts by choosing from a set of predetermined categories, such as $\$ 1$ to $\$ 1499, \$ 1500$ to $\$ 2999$, etc. The category ranges were not constant (the range for the upper category was nearly double that for the lower category) and the highest category included all values of $\$ 100,000$ or more. To create continuous values from these categorical data, we employed a commonly used technique of computing the mid-point of each category and assigned that value to all responses in the category, and we multiplied the top value by 1.4. Unfortunately this coding scheme by the survey designers means that we are not able to capture the full upper tail of the wealth distribution and as a consequence, our mean values for asset and wealth measures would be lower than what other similar studies report. The percent of our sample that is in this top code is $6.5 \%$ for the value of their savings account and $4.5 \%$ for the value of their investment accounts.

Table 1 shows the mean values of our variables and indicates which variables are binary $(0,1)$. The mean of net worth is $\$ 120,518$. We also calculated a median net worth (not shown in Table 1 ) of $\$ 47,799$. The average value of debt is $\$ 43,456$ and the average value for assets is $\$ 163,973$. Eighty-seven percent of respondents reported a positive value for net worth. In addition, the range of values for net worth (not shown) is large, with the lowest value being a negative net worth of $\$ 605,251$ and the highest value being $\$ 2.74$ million.

Table 1: Sample Means

\begin{tabular}{|l|c|c|l|c|c|}
\hline \multicolumn{1}{|c|}{ Variable } & Mean & $\begin{array}{c}\text { Standard } \\
\text { Deviation }\end{array}$ & \multicolumn{1}{|c|}{ Variable } & Mean & $\begin{array}{c}\text { Standard } \\
\text { Deviation }\end{array}$ \\
\hline Net Worth & $\$ 120,518$ & $\$ 213,313$ & Lives in Midwest $(0,1)$ & 0.248 & 0.43 \\
\hline Total Debt & $\$ 43,456$ & $\$ 78,467$ & Lives in West $(0,1)$ & 0.223 & 0.42 \\
\hline Total Assets & $\$ 163,973$ & $\$ 247,140$ & Lives in South $(0,1)$ & 0.323 & 0.47 \\
\hline Religious Beliefs Index & 6.69 & 2.33 & Divorced $(0,1)$ & 0.125 & 0.33 \\
\hline Household Income & $\$ 44,737$ & $\$ 44,239$ & Widowed $(0,1)$ & 0.072 & 0.26 \\
\hline Hispanic $(0,1)$ & 0.077 & 0.27 & Never married $(0,1)$ & 0.095 & 0.29 \\
\hline Black (0,1) & 0.096 & 0.29 & Married/Cohabitating $(0,1)$ & 0.641 & 0.48 \\
\hline White $(0,1)$ & 0.827 & 0.38 & Number of children in household & 2.168 & 1.74 \\
\hline Age in years & 47.7 & 15.44 & Ever had children $(0,1)$ & 0.807 & 0.39 \\
\hline Not high school graduate $(0,1)$ & 0.118 & 0.32 & Have a positive net worth $(0,1)$ & 0.869 & 0.34 \\
\hline High school graduate $(0,1)$ & 0.308 & 0.46 & Own a home $(0,1)$ & 0.687 & 0.46 \\
\hline Has some college $(0,1)$ & 0.287 & 0.45 & Have debt $(0,1)$ & 0.782 & 0.41 \\
\hline College graduate $(0,1)$ & 0.181 & 0.39 & Have a savings account $(0,1)$ & 0.789 & 0.41 \\
\hline Has advanced degree $(0,1)$ & 0.106 & 0.31 & Have an investment account $(0,1)$ & 0.350 & 0.48 \\
\hline Lives in Metropolitan area $(0,1)$ & 0.806 & 0.40 & Ever Received Inheritance $(0,1)$ & 0.273 & 0.45 \\
\hline Lives in Northeast $(0,1)$ & 0.206 & 0.40 & & & \\
\hline
\end{tabular}

Notes: Sampling weights used. Sample size is 6,296 households 


\section{Measurement of Religious Beliefs}

The NSFH included two questions that pertained specifically to religious belief. Respondents were asked to indicate the degree to which they agreed with the following statements: (1) "The Bible is God's word and everything happened or will happen exactly as it says" and (2) "The Bible is the answer to all important human problems." We used the primary respondent's answers to these two questions to construct an index to measure the household's religious belief. In households with two respondents, we compared the two sets of survey answers to determine if the two respondents' answers were consistent. In approximately $40 \%$ of the cases the two respondents had identical responses to both questions and in an additional $40 \%$ their answers differed by only one unit on the Likert scale. The two respondents had completely opposite answers for each of these two survey questions (strongly agree versus strongly disagree) in only about $1 \%$ of the households.

To construct an index of religious belief, we reverse coded the Likert scale data so that responses ranged from $1=$ Strongly Disagree to $5=$ Strongly Agree and summed the responses to these two questions so that possible values ranged from 2 to 10 . Respondents with religious beliefs measured as a 10 on our index are the most literalist in their beliefs while those with a 2 are the least literalist. Table 1 shows a mean of 6.69 for our index. By combining responses to the two questions, we were able to create a measure that displayed greater variability than what we would obtain by using responses to just one of the questions, but this approach also raises the question of how reliable the index is as a measure of religious beliefs. The beliefs of a person who strongly agrees with the first statement above but strongly disagrees with the second statement would be very different from those of someone who neither agreed nor disagreed with both statements, yet both respondents would have the same summed index value on our scale. In order for our index to be meaningful, responses should be reasonably consistent across the two questions. To evaluate the index for consistency, we computed Cronbach's Alpha. The value for our religion index is 0.86 . Normally, a value of at least 0.70 is considered to be an acceptable level of internal consistency.

A difficulty for researchers interested in using religion beliefs as a variable in data analysis is how to quantify it. Our literalist index has no true meaning if an individual moves from 6 to 7 on the scale. An alternative could be to categorize the ends of the distribution into "literalist" and "not literalist" designations and compare to the median response of 6 . We did try that with our analysis that follows but the results were almost entirely not significant. While creating our index is an attempt to measure a value that truly cannot be measured, categorizing it into binary variables takes out any variation in the degree of literal interpretation. How the religious beliefs variable is quantified is a tradeoff but we find that our index gives reasonable results.

The NSFH also asked the respondents about their denominational affiliation and their frequency of attendance at religious services. We examined the religious beliefs index for several of the larger denominational affiliations and found additional evidence to support our contention that denomination is an imperfect indicator of religious beliefs. One example comes from among those who reported an affiliation as Baptists, a denomination usually considered to be Conservative Protestant (Roof and McKinney 1987). While 33\% did strongly agree with both biblical interpretation statements (registering 10 on the religious beliefs index), $6 \%$ disagreed or strongly disagreed with at least one of those statements and $15 \%$ are neutral on both statements. In contrast, Episcopalians and Presbyterians are labeled as Mainline Protestant in Steensland, et al. (2000), but 19\% of Episcopalians and 39\% of Presbyterians agreed or strongly agreed with at least one biblical interpretation statement.

Some studies that examine the impact of religion on economic outcomes have used frequency of church attendance to serve as an indicator of religiosity (McCleary and Barro 2006). While the NSFH includes information on this variable, we do not find it to be a good indicator about religious beliefs either. Of the respondents who said they never attended religious services, $28 \%$ agreed or strongly agreed with the statement "The Bible is God's word and everything happened or will happen exactly as it says". Among the respondents who attended services at least once per month, $15 \%$ disagreed or strongly disagreed with that same statement.

Our sample also included 105 households in which the primary respondent self-identified as being Jewish and 49 households in which the primary respondent self-identified as Islamic, Hindu, Buddhist, or another nonwestern religion. While the survey questions on Biblical interpretation may not seem to apply to these religions, the respondents did answer these two questions and gave a variety of responses. To determine what impact these 
respondents may have on our analysis, we ran the statistical analysis shown in Tables 2 and 3 on our sample, both with and without these 154 respondents. Because our results were very similar with and without these respondents, we decided to keep these 154 respondents in the analysis.

\section{Measurement of Income Variables}

We employed two financial variables in the tests. The first is household income, comprised of the total income from all sources for both the primary and secondary respondents. The second financial variable is an indicator for whether or not the primary or secondary respondent had ever received an inheritance of more than $\$ 1,000$. We regard this variable as an indicator of the assistance provided by parents, both in the monetary form and in the sense of transmitting financial knowledge to the younger generation. Both of the income variables are expected to have a positive relationship with wealth. We should note here that because of the possible endogeneity between the income variables and wealth, our regression output should be interpreted as being descriptive rather than evidence of a causal relationship. Table 1 shows that the average household income is $\$ 44,737$ and that $27 \%$ of the sample households had received an inheritance of at least $\$ 1,000$.

\section{Measurement of Demographic Variables}

In order to isolate the specific effect of religious belief, the tests also employed a set of demographic variables that have been used in previous studies of wealth. These include race/ethnicity, education, number of children in the household and whether the respondents ever had children, age, marital status, region of the United States in which the household resides, and whether the residence is located in an urban area. Although our focus here is on the household, some demographic variables such as race, age and education could not realistically be measured at the household level if there were two respondents in the household. For the race/ethnicity variable, we used the race/ethnicity of the primary respondent. For age and level of education, we used the age of the older of the two respondents and the highest education level achieved by either the primary or secondary respondent. Our reasoning was that the household unit would benefit from the additional years of experience and education of the oldest or most educated person.

Table 1 shows that the average household age is approximately 48 years old. Nearly $83 \%$ of the primary respondents are White, almost $10 \%$ are Black, and $8 \%$ are Hispanic. Twelve percent of the sample did not graduate from high school, $31 \%$ are high school graduates, $29 \%$ attended college, $18 \%$ are college graduates, and $11 \%$ hold an advanced degree. A plurality of the households in the sample, 32\%, lives in the South United States, $25 \%$ in the Midwest, $22 \%$ in the West and $21 \%$ in the Northeast. Eighty-one percent live in a metropolitan area. The majority are married couple/cohabitating households at $64 \%$. Of the households with no secondary respondent, $13 \%$ are divorced, $7 \%$ are widowed, and $10 \%$ have never married. The households in our sample have an average of slightly more than 2 children and $81 \%$ of the respondents in these households have had a child at some point in their lives. A correlation analysis of all of the variables in our model showed that only the variables "number of children" and "ever have children" had a correlation coefficient in absolute value of greater than 0.5.

\section{REGRESSION RESULTS}

In what follows, we explore the nature of the association between religious beliefs and wealth by testing our three hypotheses. Table 2 reports the results of a set of multivariate regressions on the level of net worth. The first column contains the coefficient estimates from a generalized linear model (GLM) regression on household net worth using the whole sample and tests our first hypothesis that Biblical literalism is associated with a lower level of wealth. The coefficient on the religious beliefs variable supports this hypothesis. Each 1 unit increase in the religion index (toward more literalist) is associated with a $\$ 2,632$ decline in net worth, all else held constant. The consequences for wealth are significant. The $\$ 21,056$ predicted decline in net worth associated with going from a religious beliefs measure of 2 to a 10 represents $17.5 \%$ of the $\$ 120,518$ sample mean for net worth.

The results from the other variables show that net worth rises with income, age and education. The net worth of married/cohabitating households (the omitted category) is higher than that of households headed by widows, but lower than the net worth of households headed by never married individuals, all else constant. This 
latter effect is due to our coding of married and cohabitating households together being the omitted group. Among the households with a primary and secondary respondent, there was not always agreement from these two individuals in stating their marital status so we could not clearly define which of these households were married and which were cohabitating. Households in which the respondents have had children have a higher level of net worth, all else equal, but there seems to be no effect of the number of children. Households that have received an inheritance have a higher level of net worth. Blacks have significantly lower net worth than Whites, the omitted race category. Households that are located in the West have higher net worth than those in the South (the omitted category), all else held constant.

Table 2: GLM and Quantile Regression Results on Net Worth in Thousands of Dollars (standard error in parentheses)

\begin{tabular}{|c|c|c|c|c|c|c|}
\hline & GLM & $\begin{array}{c}\text { 10th } \\
\text { percentile }\end{array}$ & $\begin{array}{c}\text { 25th } \\
\text { percentile }\end{array}$ & $\begin{array}{c}\text { 50th } \\
\text { percentile }\end{array}$ & $\begin{array}{c}\text { 75th } \\
\text { percentile }\end{array}$ & $\begin{array}{c}\text { 90th } \\
\text { percentile }\end{array}$ \\
\hline Intercept & $\begin{array}{c}218.392 * * \\
(23.764)\end{array}$ & $\begin{array}{c}-37.549 * * \\
(1.926)\end{array}$ & $\begin{array}{c}-66.307 * * \\
(3.962)\end{array}$ & $\begin{array}{c}-89.919 * * \\
(7.583)\end{array}$ & $\begin{array}{c}-91.960^{* *} \\
(16.494)\end{array}$ & $\begin{array}{c}103.627 * * \\
(24.234)\end{array}$ \\
\hline $\begin{array}{l}\text { Religious Belief } \\
\text { Index }\end{array}$ & $\begin{array}{c}-2.632 * * \\
(0.916)\end{array}$ & $\begin{array}{c}0.188 \\
(0.097)\end{array}$ & $\begin{array}{l}-0.036 \\
(0.142)\end{array}$ & $\begin{array}{c}-1.620 * * \\
(0.280)\end{array}$ & $\begin{array}{c}-2.107 * * \\
(0.645)\end{array}$ & $\begin{array}{l}-2.836^{*} \\
(1.239)\end{array}$ \\
\hline Age & $\begin{array}{c}5.264 * * \\
(0.881)\end{array}$ & $\begin{array}{c}0.769 * * \\
(0.071)\end{array}$ & $\begin{array}{l}1.384 * * \\
(0.172)\end{array}$ & $\begin{array}{l}1.645^{* *} \\
(0.348)\end{array}$ & $\begin{array}{c}1.22 \\
(0.715) \\
\end{array}$ & $\begin{array}{l}1.687 * \\
(0.852) \\
\end{array}$ \\
\hline Age Squared & $\begin{array}{l}-0.018^{*} \\
(0.008)\end{array}$ & $\begin{array}{c}-0.004 * * \\
(0.001)\end{array}$ & $\begin{array}{c}-0.005^{* *} \\
(0.002)\end{array}$ & $\begin{array}{c}0.003 \\
(0.004)\end{array}$ & $\begin{array}{l}0.020^{*} \\
(0.008)\end{array}$ & $\begin{array}{l}0.025^{* *} \\
(0.008)\end{array}$ \\
\hline $\begin{array}{l}\text { Received } \\
\text { Inheritance }\end{array}$ & $\begin{array}{c}50.375^{* *} \\
(4.661)\end{array}$ & $\begin{array}{l}4.58 * * \\
(0.638)\end{array}$ & $\begin{array}{c}12.885^{* * *} \\
(1.108)\end{array}$ & $\begin{array}{c}24.984 * * \\
(3.192)\end{array}$ & $\begin{array}{c}49.761 * * \\
(5.337)\end{array}$ & $\begin{array}{c}113.206^{* *} \\
(13.912)\end{array}$ \\
\hline Household Income & $\begin{array}{l}1.927 * * \\
(0.050)\end{array}$ & $\begin{array}{l}0.287 * * \\
(0.024)\end{array}$ & $\begin{array}{l}0.656 * * \\
(0.038)\end{array}$ & $\begin{array}{l}1.270 * * \\
(0.073)\end{array}$ & $\begin{array}{l}2.161 * * \\
(0.120)\end{array}$ & $\begin{array}{l}3.235 * * \\
(0.253)\end{array}$ \\
\hline Hispanic & $\begin{array}{l}-11.421 \\
(7.983)\end{array}$ & $\begin{array}{l}-0.263 \\
(0.425)\end{array}$ & $\begin{array}{l}-1.778^{*} \\
(0.759)\end{array}$ & $\begin{array}{c}-5.628^{* *} \\
(2.060)\end{array}$ & $\begin{array}{l}-5.933 \\
(3.433)\end{array}$ & $\begin{array}{l}-5.882 \\
(7.743)\end{array}$ \\
\hline Black & $\begin{array}{c}-23.007 * * \\
(5.652)\end{array}$ & $\begin{array}{c}-1.222 * * \\
(0.399)\end{array}$ & $\begin{array}{c}-4.752 * * \\
(0.538)\end{array}$ & $\begin{array}{c}-10.487 * * \\
(1.229)\end{array}$ & $\begin{array}{c}-15.771 * * \\
(3.440)\end{array}$ & $\begin{array}{c}-17.014 * * \\
(4.882)\end{array}$ \\
\hline $\begin{array}{l}\text { High school } \\
\text { graduate }\end{array}$ & $\begin{array}{c}24.608 * * \\
(6.610)\end{array}$ & $\begin{array}{c}1.674 * * \\
(0.463)\end{array}$ & $\begin{array}{c}5.125^{* *} \\
(0.789)\end{array}$ & $\begin{array}{c}12.192 * * \\
(1.623)\end{array}$ & $\begin{array}{c}11.415^{* *} \\
(3.421)\end{array}$ & $\begin{array}{l}13.321 * \\
(5.340) \\
\end{array}$ \\
\hline Has some college & $\begin{array}{c}27.632 * * \\
(6.988)\end{array}$ & $\begin{array}{l}1.505 * * \\
(0.512) \\
\end{array}$ & $\begin{array}{l}4.445 * * \\
(0.741) \\
\end{array}$ & $\begin{array}{l}8.178 * * \\
(1.608) \\
\end{array}$ & $\begin{array}{c}6.182 \\
(3.835) \\
\end{array}$ & $\begin{array}{l}10.201 \\
(6.978) \\
\end{array}$ \\
\hline College graduate & $\begin{array}{c}46.083 * * \\
(7.971)\end{array}$ & $\begin{array}{c}1.818 \\
(0.933)\end{array}$ & $\begin{array}{l}7.468 * * \\
(1.265)\end{array}$ & $\begin{array}{c}17.751 * * \\
(3.139)\end{array}$ & $\begin{array}{c}28.538 * * \\
(6.839)\end{array}$ & $\begin{array}{c}47.531 * * \\
(13.621)\end{array}$ \\
\hline Advanced degree & $\begin{array}{l}45.054 * * \\
(9.226)\end{array}$ & $\begin{array}{c}4.811 \\
(3.590)\end{array}$ & $\begin{array}{c}17.045 * * \\
(2.626)\end{array}$ & $\begin{array}{l}30.686 * * \\
(7.321)\end{array}$ & $\begin{array}{c}46.367 * * \\
(8.105)\end{array}$ & $\begin{array}{l}58.722^{* *} \\
(20.494)\end{array}$ \\
\hline Divorced & $\begin{array}{l}-9.846 \\
(5.231)\end{array}$ & $\begin{array}{c}-1.461 * * \\
(0.396)\end{array}$ & $\begin{array}{c}-3.858 * * \\
(0.725)\end{array}$ & $\begin{array}{c}-4.092 * * \\
(1.501) \\
\end{array}$ & $\begin{array}{c}2.165 \\
(3.601) \\
\end{array}$ & $\begin{array}{c}4.483 \\
(7.037) \\
\end{array}$ \\
\hline Widowed & $\begin{array}{c}-25.239 * * \\
(7.894)\end{array}$ & $\begin{array}{c}-2.260 * * \\
(0.601)\end{array}$ & $\begin{array}{c}-8.140 * * \\
(1.228)\end{array}$ & $\begin{array}{c}-15.682 * * \\
(2.967)\end{array}$ & $\begin{array}{c}-17.658^{*} \\
(7.699)\end{array}$ & $\begin{array}{l}-9.764 \\
(7.389)\end{array}$ \\
\hline Never married & $\begin{array}{l}14.752 * \\
(7.316)\end{array}$ & $\begin{array}{c}1.817 * * \\
(0.531)\end{array}$ & $\begin{array}{c}4.537 * * \\
(0.841)\end{array}$ & $\begin{array}{c}12.824 * * \\
(1.830)\end{array}$ & $\begin{array}{c}19.193 * * \\
(3.790)\end{array}$ & $\begin{array}{c}26.272 * * \\
(6.915)\end{array}$ \\
\hline Number of children & $\begin{array}{l}-0.686 \\
(1.448)\end{array}$ & $\begin{array}{l}-0.003 \\
(0.102)\end{array}$ & $\begin{array}{l}-0.316 \\
(0.212)\end{array}$ & $\begin{array}{l}-0.709 \\
(0.455)\end{array}$ & $\begin{array}{l}-0.042 \\
(0.913)\end{array}$ & $\begin{array}{l}-0.006 \\
(0.883)\end{array}$ \\
\hline Ever had children & $\begin{array}{c}20.109 * * \\
(6.503)\end{array}$ & $\begin{array}{c}1.539 * * \\
(0.537)\end{array}$ & $\begin{array}{c}5.738 * * \\
(0.863)\end{array}$ & $\begin{array}{c}15.991 * * \\
(1.837)\end{array}$ & $\begin{array}{c}15.622 * * \\
(3.936) \\
\end{array}$ & $\begin{array}{c}19.606 * * \\
(6.901) \\
\end{array}$ \\
\hline Live in Northeast & $\begin{array}{c}6.018 \\
(5.625)\end{array}$ & $\begin{array}{l}-1.152 \\
(0.435)\end{array}$ & $\begin{array}{c}-2.251 * * \\
(0.776)\end{array}$ & $\begin{array}{c}0.02 \\
(2.339)\end{array}$ & $\begin{array}{c}6.012 \\
(3.736)\end{array}$ & $\begin{array}{c}17.967^{* *} \\
(6.595)\end{array}$ \\
\hline Live in Midwest & $\begin{array}{l}-5.933 \\
(4.876)\end{array}$ & $\begin{array}{c}0.226 \\
(0.432)\end{array}$ & $\begin{array}{c}0.572 \\
(0.688)\end{array}$ & $\begin{array}{l}-0.455 \\
(1.196)\end{array}$ & $\begin{array}{l}-4.628 \\
(3.210)\end{array}$ & $\begin{array}{l}-7.518 \\
(4.718)\end{array}$ \\
\hline Live in West & $\begin{array}{c}18.434 * * \\
(5.659) \\
\end{array}$ & $\begin{array}{c}-1.836^{* *} \\
(0.460)\end{array}$ & $\begin{array}{l}-1.824^{*} \\
(0.731) \\
\end{array}$ & $\begin{array}{c}0.79 \\
(1.944) \\
\end{array}$ & $\begin{array}{c}8.081 \\
(4.197) \\
\end{array}$ & $\begin{array}{c}22.792 * * \\
(8.500)\end{array}$ \\
\hline Metropolitan area & $\begin{array}{l}-3.163 \\
(4.746)\end{array}$ & $\begin{array}{l}-0.262 \\
(0.502)\end{array}$ & $\begin{array}{l}-0.295 \\
(0.584)\end{array}$ & $\begin{array}{l}-0.685 \\
(1.174)\end{array}$ & $\begin{array}{l}-1.611 \\
(2.919)\end{array}$ & $\begin{array}{c}-6.11 \\
(5.717)\end{array}$ \\
\hline
\end{tabular}

Notes: $* * p<0.01 ;{ }^{*} p<0.05$. The null hypothesis that the regression coefficients are all equal to zero is rejected by chi-square tests at less than the $1 \%$ level of significance for every regression equation. 
While these results are evidence of a negative association between literalist beliefs and wealth, we have no assurance that the relationship is robust across the whole wealth distribution. Are more literalist beliefs associated with lower wealth at all levels of wealth? We hypothesized that the relationship between religion and wealth for households in the low wealth group is different from that for the higher wealth households because a conservative approach to investment may benefit low wealth households while it could ultimately have an adverse effect on the wealth of high wealth households. The fact that the distribution of the net worth variable is non-normal and displays a significant degree of skewness supports this possibility. Many respondents in the survey reported low or zero net worth but a few reported very high net worth. In order to account for these issues and to evaluate the robustness of the results across the sample, we conducted a set of quantile regressions using net worth and the same set of independent variables.

The quantile regression approach possesses several advantages for researchers. First, by running the quantile regressions, we can analyze the effects of the independent variables within specific ranges of values of the dependent variable rather than across the whole distribution. Second, the method reduces the sensitivity of the regression estimates to the influence of outliers, which is a potential problem here. Quantile regression makes no distributional assumption of the error term, so it has considerable robustness. Finally, differences in the regression estimates across quantiles can be interpreted as variations in the response of the dependent variable to the regressors at different points in the wealth distribution (Bushinsky 1998; Koenker and Hallock 2001).

The quantile regression results are presented in Columns 2 to 6 of Table 2. A comparison of the coefficient estimates across the different quantiles shows that the relationship with some of the independent variables is fairly consistent across the whole wealth distribution. Blacks have less wealth than Whites at all levels of wealth, all else held constant. Increases in income lead to increases in wealth across the distribution, all else held constant, and having children is associated with a higher level of wealth. The coefficients on all of these variables have the same signs and are significant in all the quantile regressions.

At the same time, variations among the coefficient estimates in the quantile regressions do exist, and these differences are worthy of interest. For the lowest $10 \%$ alone, having a college or advanced degree has no significant relationship with wealth. Having only some college education is not statistically significant in the $75^{\text {th }}$ and $90^{\text {th }}$ percentile, all else held constant. The effect of residence also varies across the quantiles. For the $10^{\text {th }}$ and $25^{\text {th }}$ percentiles, households living in the Northeast or the West have a lower level of wealth than those in the South, but the opposite is true for households in the 90th percentile.

Most important for our focus of interest, the coefficient on the religious beliefs index differs from the GLM estimate, and it varies markedly across the quantiles. For the $10^{\text {th }}$ and the $25^{\text {th }}$ percentile groups, the coefficient is not significant, indicating that at lower levels of net worth religious attitudes have no discernable association with net worth, all else held constant. This contrasts sharply with the results for the rest of the net worth distribution. In every other segment of the distribution, holding more strongly literalist beliefs is associated with a lower level of net worth. Moreover, the adverse association of this variable rises as we move up the net worth distribution. For households in the $50^{\text {th }}$ percentile, a one point increase in the religious beliefs index corresponds to a $\$ 1,620$ decrease in net worth, but in the upper $90^{\text {th }}$ percentile, each one point increase in the index is associated with a $\$ 2,836$ drop in net worth, all else held constant.

So far we have found that overall more literalist households have a lower level of net worth but it is households in the upper end of the wealth distribution that are most strongly affected and are driving this result. To further understand the effect of religious belief, we employ a set of logit regressions reported in Table 3 to analyze our third hypothesis on the composition of the components of wealth. Here we ask three related questions. First, is the composition of net worth different for these more literalist households? To answer this question, we decompose the net worth variable to examine the relationship between religious beliefs and the probability of owning each of the asset categories of having a savings account (Column 1), owning a home (Column 2), having an investment account (Column 3) and of having debt (Column 4). The coefficients from the logit regression indicate the effects of each explanatory variable on the log of the odds (e.g. two-to-three or five-to-four) of having the asset. The results indicate a clear association between literalist beliefs and the composition of household net worth. Although there is no correspondence between religious beliefs and the likelihood of having a savings account or of carrying debt, 
being more literalist is associated with a significant rise in the probability that the household owns a home and a decrease in the probability that it has an investment account, all else held constant.

Table 3 Logistic Regressions (standard errors are in parentheses)

\begin{tabular}{|c|c|c|c|c|c|c|}
\hline & $\begin{array}{c}\text { Have Savings } \\
\text { Account }\end{array}$ & $\begin{array}{c}\text { Have Investment } \\
\text { Account }\end{array}$ & Have Debt & Own Home & Ever Inherited & $\begin{array}{c}\text { Have Positive } \\
\text { Net Worth }\end{array}$ \\
\hline Intercept & $\begin{array}{l}1.104 * * \\
(0.419)\end{array}$ & $\begin{array}{c}-3.520 * * \\
(0.403)\end{array}$ & $\begin{array}{l}-0.852 \\
(0.464) \\
\end{array}$ & $\begin{array}{c}-4.787 * * \\
(0.383)\end{array}$ & $\begin{array}{c}-5.536 * * \\
(0.426) \\
\end{array}$ & $\begin{array}{c}-2.138 * * \\
(0.457)\end{array}$ \\
\hline Religious Belief Index & $\begin{array}{l}-0.024 \\
(0.017) \\
\end{array}$ & $\begin{array}{c}-0.034 * \\
(0.014)\end{array}$ & $\begin{array}{c}0.018 \\
(0.018) \\
\end{array}$ & $\begin{array}{l}0.033 * \\
(0.015) \\
\end{array}$ & $\begin{array}{c}-0.058 * * \\
(0.015)\end{array}$ & $\begin{array}{l}0.046 * \\
(0.019) \\
\end{array}$ \\
\hline Age & $\begin{array}{c}-0.02 \\
(0.016) \\
\end{array}$ & $\begin{array}{c}0.041 * * \\
(0.015) \\
\end{array}$ & $\begin{array}{c}0.129 * * \\
(0.017)\end{array}$ & $\begin{array}{c}0.148 * * \\
(0.014) \\
\end{array}$ & $\begin{array}{c}0.116 * * \\
(0.015) \\
\end{array}$ & $\begin{array}{c}0.066 * * \\
(0.017) \\
\end{array}$ \\
\hline Age Squared & $\begin{array}{c}0.0005 * * \\
(0.0001) \\
\end{array}$ & $\begin{array}{c}-0.0003 * \\
(0.0001) \\
\end{array}$ & $\begin{array}{l}-0.002 * * \\
(0.0002)\end{array}$ & $\begin{array}{l}-0.001 * * \\
(0.0001)\end{array}$ & $\begin{array}{c}-0.001 * * \\
(0.0001)\end{array}$ & $\begin{array}{c}-0.0003 \\
(0.0002) \\
\end{array}$ \\
\hline $\begin{array}{l}\text { Ever Received } \\
\text { Inheritance } \\
\end{array}$ & $\begin{array}{c}0.584 * * \\
(0.094) \\
\end{array}$ & $\begin{array}{c}0.441 * * \\
(0.071) \\
\end{array}$ & $\begin{array}{l}-0.217 * \\
(0.086) \\
\end{array}$ & $\begin{array}{c}0.476 * * \\
(0.081) \\
\end{array}$ & & $\begin{array}{c}0.759 * * \\
(0.117) \\
\end{array}$ \\
\hline Household Income & $\begin{array}{c}0.039 * * \\
(0.002) \\
\end{array}$ & $\begin{array}{c}0.016 * * \\
(0.001) \\
\end{array}$ & $\begin{array}{c}0.012 * * \\
(0.002) \\
\end{array}$ & $\begin{array}{c}0.027 * * \\
(0.002) \\
\end{array}$ & $\begin{array}{l}0.002 * \\
(0.001) \\
\end{array}$ & $\begin{array}{c}0.034 * * \\
(0.003) \\
\end{array}$ \\
\hline Hispanic & $\begin{array}{l}-0.201 \\
(0.129) \\
\end{array}$ & $\begin{array}{c}-0.545 * * \\
(0.154) \\
\end{array}$ & $\begin{array}{c}-0.290^{*} \\
(0.140) \\
\end{array}$ & $\begin{array}{c}-0.375^{* *} \\
(0.122) \\
\end{array}$ & $\begin{array}{c}-0.814 * * \\
(0.173) \\
\end{array}$ & $\begin{array}{c}-0.328^{*} \\
(0.137) \\
\end{array}$ \\
\hline Black & $\begin{array}{c}-0.641 * * \\
(0.091) \\
\end{array}$ & $\begin{array}{c}-0.435^{* *} \\
(0.100) \\
\end{array}$ & $\begin{array}{l}-0.221 * \\
(0.100) \\
\end{array}$ & $\begin{array}{c}-0.781 * * \\
(0.088) \\
\end{array}$ & $\begin{array}{c}-0.806^{* * *} \\
(0.110) \\
\end{array}$ & $\begin{array}{c}-0.693 * * \\
(0.098) \\
\end{array}$ \\
\hline High school graduate & $\begin{array}{c}0.763 * * \\
(0.104) \\
\end{array}$ & $\begin{array}{c}1.011 * * \\
(0.156) \\
\end{array}$ & $\begin{array}{c}0.144 \\
(0.106) \\
\end{array}$ & $\begin{array}{c}0.333 * * \\
(0.103) \\
\end{array}$ & $\begin{array}{c}0.885 * * \\
(0.123) \\
\end{array}$ & $\begin{array}{c}0.658 * * \\
(0.114) \\
\end{array}$ \\
\hline Has some college & $\begin{array}{l}1.169 * * \\
(0.114) \\
\end{array}$ & $\begin{array}{c}1.468 * * \\
(0.158) \\
\end{array}$ & $\begin{array}{c}0.530 * * \\
(0.119) \\
\end{array}$ & $\begin{array}{c}0.321 * * \\
(0.110) \\
\end{array}$ & $\begin{array}{l}1.029 * * \\
(0.131) \\
\end{array}$ & $\begin{array}{c}0.570 * * \\
(0.123) \\
\end{array}$ \\
\hline College graduate & $\begin{array}{l}1.627 * * \\
(0.155) \\
\end{array}$ & $\begin{array}{c}1.744 * * \\
(0.166) \\
\end{array}$ & $\begin{array}{c}0.639 * * \\
(0.148) \\
\end{array}$ & $\begin{array}{c}0.756 * * \\
(0.135) \\
\end{array}$ & $\begin{array}{c}1.287 * * \\
(0.142) \\
\end{array}$ & $\begin{array}{c}0.846 * * \\
(0.166) \\
\end{array}$ \\
\hline Has advanced degree & $\begin{array}{l}1.702 * * \\
(0.222)\end{array}$ & $\begin{array}{c}1.476 * * \\
(0.181) \\
\end{array}$ & $\begin{array}{c}0.424 * \\
(0.179) \\
\end{array}$ & $\begin{array}{c}0.525 * * \\
(0.163) \\
\end{array}$ & $\begin{array}{l}1.167 * * \\
(0.158) \\
\end{array}$ & $\begin{array}{c}0.507^{*} \\
(0.209) \\
\end{array}$ \\
\hline Divorced & $\begin{array}{l}-0.233^{*} \\
(0.091)\end{array}$ & $\begin{array}{c}-0.346 * * \\
(0.093)\end{array}$ & $\begin{array}{c}-0.391 * * \\
(0.096)\end{array}$ & $\begin{array}{c}-0.931 * * \\
(0.084)\end{array}$ & $\begin{array}{c}-0.044 \\
(0.091) \\
\end{array}$ & $\begin{array}{c}-0.644 * * \\
(0.098)\end{array}$ \\
\hline Widowed & $\begin{array}{c}-0.091 \\
(0.135) \\
\end{array}$ & $\begin{array}{c}0.132 \\
(0.134) \\
\end{array}$ & $\begin{array}{c}0.161 \\
(0.128) \\
\end{array}$ & $\begin{array}{c}-0.488 * * \\
(0.125)\end{array}$ & $\begin{array}{c}0.627 * * \\
(0.117)\end{array}$ & $\begin{array}{l}-0.309 \\
(0.160) \\
\end{array}$ \\
\hline Never married & $\begin{array}{c}0.095 \\
(0.130) \\
\end{array}$ & $\begin{array}{c}-0.092 \\
(0.124) \\
\end{array}$ & $\begin{array}{c}-0.645^{* *} \\
(0.131)\end{array}$ & $\begin{array}{c}-0.906^{* *} \\
(0.118) \\
\end{array}$ & $\begin{array}{c}0.259 \\
(0.133) \\
\end{array}$ & $\begin{array}{c}-0.405^{* *} \\
(0.129) \\
\end{array}$ \\
\hline Number of children & $\begin{array}{c}-0.145^{*} * \\
(0.025)\end{array}$ & $\begin{array}{c}-0.096 * * \\
(0.027)\end{array}$ & $\begin{array}{l}-0.042 \\
(0.024)\end{array}$ & $\begin{array}{l}-0.016 \\
(0.023) \\
\end{array}$ & $\begin{array}{l}-0.058 * \\
(0.025) \\
\end{array}$ & $\begin{array}{c}-0.031 \\
(0.026)\end{array}$ \\
\hline Ever had children & $\begin{array}{c}0.067 \\
(0.122) \\
\end{array}$ & $\begin{array}{l}-0.075 \\
(0.106)\end{array}$ & $\begin{array}{l}-0.003 \\
(0.124) \\
\end{array}$ & $\begin{array}{c}0.454 * * \\
(0.104)\end{array}$ & $\begin{array}{l}-0.022 \\
(0.111) \\
\end{array}$ & $\begin{array}{c}0.138 \\
(0.126) \\
\end{array}$ \\
\hline Live in Northeast & $\begin{array}{c}0.307 * * \\
(0.102)\end{array}$ & $\begin{array}{l}-0.125 \\
(0.091)\end{array}$ & $\begin{array}{c}-0.290 * * \\
(0.103)\end{array}$ & $\begin{array}{c}-0.453 * * \\
(0.093)\end{array}$ & $\begin{array}{c}0.002 \\
(0.094)\end{array}$ & $\begin{array}{c}-0.455^{* *} \\
(0.109)\end{array}$ \\
\hline Live in Midwest & $\begin{array}{c}0.542 * * \\
(0.087)\end{array}$ & $\begin{array}{c}0.125 \\
(0.078) \\
\end{array}$ & $\begin{array}{l}-0.087 \\
(0.091)\end{array}$ & $\begin{array}{c}-0.074 \\
(0.081)\end{array}$ & $\begin{array}{c}0.016 \\
(0.082) \\
\end{array}$ & $\begin{array}{c}0.046 \\
(0.101) \\
\end{array}$ \\
\hline Live in West & $\begin{array}{c}0.375 * * \\
(0.103)\end{array}$ & $\begin{array}{c}0.042 \\
(0.089) \\
\end{array}$ & $\begin{array}{c}0.131 \\
(0.111)\end{array}$ & $\begin{array}{c}-0.491 * * \\
(0.093)\end{array}$ & $\begin{array}{c}0.026 \\
(0.094) \\
\end{array}$ & $\begin{array}{l}-0.132 \\
(0.115)\end{array}$ \\
\hline Metropolitan area & $\begin{array}{c}0.135 \\
(0.083) \\
\end{array}$ & $\begin{array}{c}0.087 \\
(0.076) \\
\end{array}$ & $\begin{array}{l}-0.052 \\
(0.089) \\
\end{array}$ & $\begin{array}{c}-0.322 * * \\
(0.079)\end{array}$ & $\begin{array}{c}-0.069 \\
(0.078)\end{array}$ & $\begin{array}{l}-0.133 \\
(0.098) \\
\end{array}$ \\
\hline
\end{tabular}

Notes: $* * p<0.01 ; * p<0.05$. The null hypotheses that all of the regression coefficients are equal to zero are rejected at less than the $1 \%$ level of significance by the likelihood ratio, score, and Wald tests for each logistic regression equation. The classification table for each equation results in the specified models classifying $81 \%$ (savings), $73 \%$ (investment), $82 \%$ (debt), $76 \%$ (home), $77 \%$ (inherit), and $85 \%$ (positive net worth) of the cases correctly when the cutoff value is 0.5 . 
Our second question relates to inheritance. Since a household's financial status is influenced by both the monetary assistance and knowledge transmitted by the older generation, it would be useful to know whether more literalist households receive the same kind of financial help from parents or other relatives that other households receive. The estimates in Column 5 of Table 3 indicate that more literalist households are significantly less likely than others to have received an inheritance of more than $\$ 1,000$.

The last question focuses on net worth itself. If literalist households have lower total net worth, are they also more likely to have the financial difficulties that are characterized by negative net worth? In order to answer this question, we examine the probability of having positive net worth. The results in Column 6 of Table 3 show that even though their total net worth is lower on average, households that are more literalist are more likely to have positive net worth, all else equal.

\section{CONCLUSION}

Previous researchers have found a relationship between religion and household wealth. Our work differs from earlier studies of this topic. Where others have used denominational affiliation as the religion variable, we constructed an index of specific religious beliefs. Using this index, we were able to focus on the direct impact of belief on households' propensity to accumulate wealth.

We proposed that their religious beliefs may lead Biblical literalists to be more inclined to take a conservative approach to investment. This strategy could have two seemingly contradictory consequences. On the one hand, following a conservative approach, a household would be less likely to undertake the kinds of activities that would lead to serious financial trouble. On the other hand, their beliefs could lead literalist households to invest less money overall and to be attracted to less risky but also lower return assets thus lowering their wealth. Using a GLM regression, we found overall that households that held more literalist religious beliefs had a significantly lower level of net worth, even when other social and economic factors were taken into account. Moreover, our logit results show that these households are less often to engage in risky financial behavior, as shown that they are more likely to not be a net debtor and so they reap the benefit of making prudent financial decisions.

However, the contradictory effects of a conservative investment approach suggest that the relationship between religious beliefs and wealth should be examined at different points in the wealth distribution, which we did with a set of quantile regressions. While it could be possible that lower wealth households with more literalist beliefs might actually have a higher net worth due to less risky financial behavior, we found that there is no association between religious beliefs and net worth for the lower end of the wealth distribution. Therefore, policymakers may help this group more with programs that, for example, increase access to education as a method to increase their earnings and wealth. For households in the middle and upper end of the wealth distribution, it could be more difficult for policymakers to devise effective policies to decrease wealth disparity because religious beliefs are also negatively impacting their wealth accumulation.

Taking a conservative approach to investment suggests that the combination of assets held by religious literalists is different from that of other households. Using a set of logit regressions, we explored this possibility. The relationship between religious belief and the composition of net worth helps to explain the source of wealth differences. Households with more strongly literalist beliefs are less likely to be in financial trouble, the benefit of a more conservative approach to investment. However, they are more likely to put their income into lower return assets such as housing and are less likely to hold higher yield but higher risk investment accounts. Over time, this would certainly result in the lower overall level of net worth for these households. Moreover, these households were less likely to have received assistance from their parents in the form of an inheritance, which can lead to successive generations of more literalist households having a lower net worth.

\section{AUTHOR INFORMATION}

E. Anne York, Ph.D. is an associate professor of economics in the School of Business at Meredith College. Her research has examined how health status affects the joint labor supply decisions of married couples; international comparisons of labor force participation rates for women and for individuals approaching retirement age; immigrant 
versus native economic status of older workers in Germany; and gender differences in the college and career aspirations of high school valedictorians. She has received Meredith College's Pauline Davis Perry faculty award for Excellence in Research. E-mail: yorka@ meredith.edu. Corresponding author.

Marilyn Dutton, Ph.D. is a retired associate professor of economics and finance in the School of Business at Meredith College and previously was an associate professor at North Carolina Central University.

\section{REFERENCES}

1. Bushinsky, Moshe. (1998). Recent advances in quantile regression models. Journal of Human Resources 33(1): 88-126.

2. Chiswick, Barry. (1986). Labor supply and investment in child quality: A study of Jewish and non-Jewish women. Review of Economics and Statistics 68(4): 700-703.

3. Darnell, Alfred and Darren Sherkat. (1997). The influence of protestant fundamentalism on educational attainment. American Sociological Review 62(2): 306-315.

4. Glass, Jennifer and Jerry Jacobs. (2005). Childhood religious conservatism and adult attainment among black and white women. Social Forces 84(1): 552-574.

5. Hackett, Conrad and D. Michael Lindsay. (2008). Measuring evangelicalism: Consequences of different operationalization strategies. Journal for the Scientific Study of Religion 47(3): 499-514

6. Heineck, Guido. (2004). Does religion influence the labor supply of married women in Germany? Journal of Socio-Economics 33(2): 307-328.

7. Johnson, David R. and Lisa A. Elliott. (1998). Sampling design effects: Do they affect the analyses of data from the National Survey of Families and Households? Journal of Marriage and the Family 60(4):9931001.

8. Keister, Lisa. (2003). Religion and wealth: The role of religious affiliation and participation in early adult asset accumulation. Social Forces 82(1): 175-207.

9. _ (2007). Upward wealth mobility: Exploring the Roman Catholic advantage. Social Forces 85(3): $1-31$.

10. (2008). Conservative protestants and wealth: How religion perpetuates asset poverty. American Journal of Sociology 113(5): 1237-1271.

11. Kelly, Claudia Smith and Blen Solomon. (2009). The influence of religion on remittances sent to relatives and friends back home. Journal of Business \& Economics Research 7(1): 91-102.

12. Koenker, Roger and Kevin Hallock. (2001). Quantile regression. Journal of Economic Perspectives 15(4): 143-156

13. Lehrer, Evelyn. (1995). The effects of religion on the labor supply of married women. Social Science Research 24: 281-301.

$14 . \quad$ (1999). Religion as a determinant of educational attainment: an economic perspective. Social Science Research 28(4): 358-379.

15. Lipford, Jody and Robert Tollison. (2003). Religious participation and income. Journal of Economic Behavior and Organization 51(2): 249-260.

16. McCleary, Rachel and Robert Barro. (2006). Religion and economy. Journal of Economic Perspectives 20(2): 49-72.

17. Roof, Wade and William McKinney. (1987). American mainline religion, its changing shape and future. New Brunswick: Rutgers University Press.

18. Regnerus, Mark, Christian Smith and David Sikkink. (1998). Who gives to the poor? The influence of religious tradition and political location on the personal generosity of Americans toward the poor. Journal for the Scientific Study of Religion 37(3): 481-493.

19. Sherkat, Darren and Alfred Darnell. (1999). The effect of parents' fundamentalism on children's educational attainment: Examining differences by gender and children's fundamentalism. Journal for the Scientific Study of Religion 38(1): 23-35.

20. $\quad$ Smith, Tom. (1990). "Classifying Protestant Denominations." Review of Religious Research. 31(3): 225245.

21. Steen, Todd. (1996). Religion and earnings: Evidence from the NLS Youth Cohort. International Journal of Social Economics 23(1): 47-58 
22. Steensland, Brian et al. (2000). The measure of American religion: Toward improving the state of the art. Social Forces 79(1):291-318.

23. Stiglitz, Joseph. (1969). The distribution of income and wealth among individuals. Econometrica 37(3): 382-397.

24. Sweet, James A and Larry L. Bumpass. (1996). The National Survey of Families and Households - Waves 1 and 2: Data description and documentation. Center for Demography and Ecology, University of Wisconsin-Madison http://www.ssc.wisc.edu/nsfh/home.htm

25. Wolff, Edward. (2010). Recent trends in household wealth in the United States: Rising debt and the middleclass squeeze — an update to 2007. Levy Economics Institute of Bard College. Working paper 589.

Retrieved 22 June 2010. Available at www.levy.org 